\title{
Communication
}

[Comunicação]

\section{Detection of the mecA gene in Staphylococcus spp. isolated from the nasal cavity of pigs - Preliminary data}

\author{
[Detecção do gene mecA em Staphylococcus spp. isolados da cavidade \\ nasal de suínos - dados preliminares] L.N. Barbosa ${ }^{2}$, D.D. Gonçalves ${ }^{2}$, L.A. Martins ${ }^{1}$
${ }^{1}$ Autônomo - Botucatu, SP
${ }^{2}$ Aluno de pós-graduação - Universidade Paranaense - Umuarama, PR \\ K.R. Silva ${ }^{1}$, I.C. Santos ${ }^{2 *}$, P.H. Sposito', E.A. Mota ${ }^{2}$, I.C.S. Caetano ${ }^{2}$,
}

Brazil is the fourth largest producer of pork in the world, producing approximately four million tons of pork in 2017. The State of Paraná contributed $21.01 \%$ of this product whereas the State of Santa Catarina constituted $28.38 \%$ (Relatório..., 2018).

To maintain a high production and export of pork, there are some very important variables that need to be considered; main amongst them is the sanitary status, one of the most important factors affecting the optimization of zootechnical performance, the epidemiological disease situation as the primary cause, bacterial agents, and consequently the use of antibiotics as a treatment (Aguilar et al., 2015). The use of antimicrobials as therapeutics or as growth promoters, even in low doses in the diet, contribute to the selection of drug-resistant microorganisms in the microbiota of these animals (Morés and Morés, 2017).

Regarding One health, the emergence of resistant bacteria is extremely important, especially when dealing with Staphylococcus spp. that are responsible for diseases in different hosts, such as cattle, birds, sheep, pigs, companion animals and humans (Coelho et al., 2007; Masson et al., 2012). These microorganisms have different modes of virulence, such as toxins, enzymes, and the presence of resistance genes, such as the mecA gene, which may be responsible for resistance to the beta-lactam class of antibiotics and has been a concern in hospital and out-of-hospital environments for decades (Blodkamp et al., 2015).

Known as methicillin-resistant Staphylococcus (MRS), they have characteristics of penicillin binding protein production, which could be due to the expression of the mecA gene. They are, thus, resistant to the whole spectrum of beta-lactam antibiotics, and are responsible for problematic infections, prolonged hospitalizations, and significant contributions to mortality rates in humans, becoming an endemic problem throughout the world (Humphreys, 2012). The objective of this study was, therefore, to carry out the genetic characterization of Staphylococcus spp. resistance to methicillin in pigs slaughtered in a slaughterhouse inspected by the Federal Inspection Service (SIF) in the northwestern region of Paraná, Brazil.

Thirty nasal swab samples were collected from adult pigs slaughtered in a SIF-inspected slaughterhouse from the northwestern region of Paraná. The 30 samples of nasal swab were collected between March and June of 2016 from adult pigs slaughtered in a SIF refrigerator in northwestern Paraná. The nasal samples were collected at the slaughter line shortly after stunning and before bleeding using a sterile swab containing Stuart transport medium (SP Labor, Presidente Prudente, São Paulo). To cover all batches slaughtered on the day, a systematic collection standard was adopted. On the day of

Recebido em 1 de julho de 2019

Aceito em 17 de outubro de 2019

*Autor para correspondência (corresponding author)

E-mail: isabela_carvalhoxd@hotmail.com 
collection, it was possible to collect nasal swab from ten animals of three distinct properties.

The samples were then stored in isothermal boxes and immediately sent to the Laboratory of Preventive Veterinary Medicine and Public Health of the Graduate Program in Animal Science with Emphasis on Bioactive Products of the Paranaense University, Umuarama, Paraná, Brazil. Each sample was cultured in Brain Heart Infusion (BHI) medium for 24 hours at $37^{\circ} \mathrm{C}$ and then seeded in Baird Parker (BP) medium for 24 to 48 hours for the isolation of Staphylococcus spp. After this period, the macroscopic and microscopic characteristics of the isolates were verified and biochemical tests (catalase and coagulase) were performed for the identification of Staphylococcus spp. based on coagulase positivity and negativity (Quinn et al., 1994).

To determine the bacterial resistance profile, the agar diffusion method was used according to the recommendations of the Clinical and Laboratory Standards Institute (CLSI, 2013). For this test, ampicillin $(10 \mu \mathrm{g})$, cefotaxime $(30 \mu \mathrm{g})$, ceftiofur $(30 \mu \mathrm{g})$, cephalothin $(30 \mu \mathrm{g})$, streptomycin $(10 \mu \mathrm{g})$, gentamicin $(10 \mu \mathrm{g})$, lincomycin $(2 \mu \mathrm{g})$, oxacillin $(1 \mu \mathrm{g})$, penicillin $(10 \mu \mathrm{g})$, sulfonamides $(300 \mu \mathrm{g})$, and trimethoprim $(5 \mu \mathrm{g})$ were used.

DNA was extracted from the isolates that were resistant to oxacillin $(1 \mu \mathrm{g})$ using the PureLink ${ }^{\mathrm{TM}}$ Genomic DNA Mini Kit (Invitrogen, USA) according to the manufacturer's instructions. Subsequently, the DNA was subjected to PCR using $5 \mu \mathrm{M}$ mecAl (AAAATCGATGGTAAAGGTTGG) and mecA2 (AGTTCTGCAGTACCGGATTTG) primers, and the reaction was performed according to the parameters previously described by Murakami et al. (1991). Negative (S. aureus ATCC 25923) and positive (S. aureus ATCC 33591) controls were used for the reaction. DNA was amplified using a thermocycler (Thermo model Px2 Thermal Cycler) and the final PCR product was subjected to electrophoresis on a $2 \%$ agarose gel stained with GelRed (Uniscience). Visualization was performed using a UV transilluminator wherein the positive sample showed a band at $533 \mathrm{bp}$.

Of the 30 swabs collected, it was possible to isolate Staphylococcus spp. from all samples (100\%). Biochemical tests yielded $12(40 \%)$ coagulase-positive isolates and 18 (60\%) coagulase-negative isolates. The four antimicrobials that had the highest resistance index were ampicillin (with $30(100 \%)$ resistant isolates), penicillin (with $29(96.66 \%)$ resistant isolates), lincomycin and trimethoprim (with 28 (93.33\%) resistant isolates each); out of the 26 $(86.66 \%)$ isolates had oxacillin resistance (Table 1). Of the 26 isolates of oxacillin resistant Staphylococcus spp., 6 (23\%) were positive for mecA (Figure 1).

Table 1. Antimicrobial resistance of 30 isolates of Staphylococcus spp. from 30 animals belonging to three distinct properties slaughtered in a federally inspected slaughterhouse in the northwestern region of Parana, Brazil, from March to June of 2016

\begin{tabular}{lll}
\hline Antimicrobials & \multicolumn{2}{c}{$\begin{array}{c}\text { Nasal Cavity } \\
\% \text { Positive }\end{array}$} \\
\hline Ampicillin $(10 \mu \mathrm{g})$ & 30 & 100 \\
Penicillin $(10 \mu \mathrm{g})$ & 29 & 96.66 \\
Lincomycin $(2 \mu \mathrm{g})$ & 28 & 93.33 \\
Trimethoprim $(5 \mu \mathrm{g})$ & 28 & 93.33 \\
Sulfonamide $(300 \mu \mathrm{g})$ & 27 & 90.00 \\
Cefotaxime $(30 \mu \mathrm{g})$ & 27 & 90.00 \\
Oxacillin $(1 \mu \mathrm{g})$ & 26 & 86.66 \\
Gentamicin $(10 \mu \mathrm{g})$ & 25 & 83.33 \\
Ceftiofur $(30 \mu \mathrm{g})$ & 22 & 73.33 \\
Streptomycin $(10 \mu \mathrm{g})$ & 21 & 70.00 \\
Cephalothin $(10 \mu \mathrm{g})$ & 21 & 70.00 \\
\hline Legend: R= Resistant. \%= Percentage
\end{tabular}




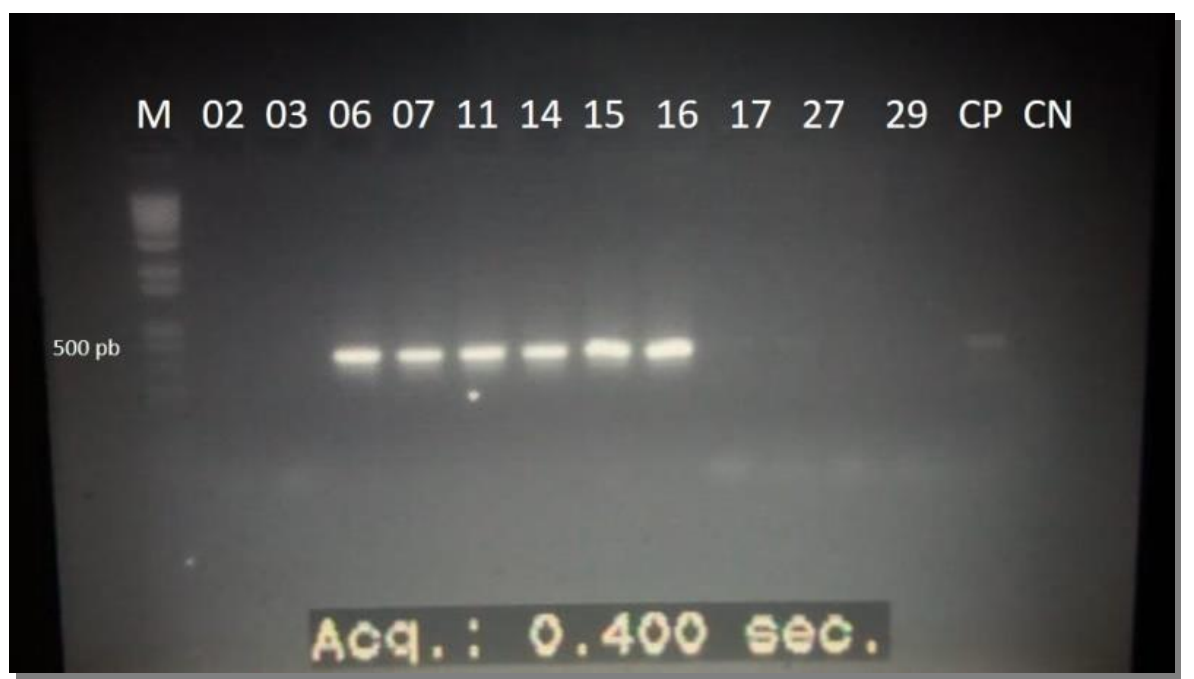

Figure 1. Samples of Staphylococcus spp. positive for the mecA gene obtained from 30 animals belonging to three distinct properties slaughtered in a federally inspected slaughterhouse in the northwestern region of Parana, Brazil, from March to June of 2016. Legend: $\mathrm{M}=$ Molecular weight marker, $\mathrm{CN}=\mathrm{Negative}$ Control, $\mathrm{CP}=$ Positive Control, Numbers $=$ tested samples.

Pork is the most commonly consumed animal meat in the world because it has a unique taste and excellent nutritional quality. To ensure its efficient production and export to several continents, swine herds in Brazil have been growing every year (Aguilar et al, 2015). However, pig production is susceptible to microbiological contamination from different sources, and Staphylococcus spp. is a major pathogen associated with skin and pulmonary infections in humans and animals (Morgan, 2008). This microorganism is found in the nasal region of swine species and is one of the key factors responsible for infectious diseases in pigs (Aguilar et al., 2015; Blodkamp et al., 2015).

Due to the importance of detection of the mecA gene in swine that will be marketed for human consumption, this study shows preliminary molecular data from a large phenotypic, molecular and epidemiological study that is still underway. Staphylococcus spp. were isolated in all the $30(100 \%)$ samples analyzed, however a study by Lima et al. (2004), investigating pig carcasses in a slaughterhouse located in the state of Minas Gerais, detected these bacteria in only 14 samples (11.7\%). The frequency of Staphylococcus spp. in this work can be explained by the choice of collection site, because Staphylococcus spp. are one of the main microorganisms present in the microbiota of pigs (Blodkamp et al., 2015).
Moreover, in the present study, resistance to different antimicrobials was observed in all the samples, with $56.66 \%$ of the isolates showing resistance to 8 or more antimicrobials; these findings corroborate those of Masson et al. (2012), wherein the antimicrobial resistance rate was also significant and $34 \%$ of the samples showed resistance to 4 or more antimicrobials tested.

In the present study it was also found that 86.66 $\%$ of Staphylococcus spp. isolated were resistant to oxacillin. Similar results were obtained by Masson et al., (2012) in a slaughterhouse in the state of Minas Gerais, wherein oxacillin resistance was found in $3.88 \%$ isolates from nasal samples of pigs.

Pertaining to the mecA gene, in this work, positive samples accounted for $23 \%$ of the studied samples, deviating from results obtained by Masson et al. (2012) who did not detect the gene in analyzed samples. The antibiotic resistance seen in our study may not necessarily be associated with the mecA gene itself, as the gene is known to have homologues. In addition to displaying similar resistance, these homologues may be present in phenotypically sensitive samples, making the search for such genes in mecA negative samples a good option to justify the lack of mecA detection (Pichon et al., 2012). The transmission of Staphylococcus spp., between 
humans and animals, particularly in swine, can be caused by different risk factors such as: handling and/or ingestion of contaminated food, poor personal hygiene, failure to use PPE for safety, health of the affected herd, and disregarding sanitary voids among other measures (Aguilar et al., 2015).

Resistance to oxacillin was found in $86.66 \%$ of the Staphylococcus spp. samples analyzed in the present study. The presence of the mecA gene was observed in $23.07 \%$ of these samples, showing that pigs are carriers of MRS, possibly mediated by the mecA gene, and that the misuse of antimicrobials in the management of the animals may be one of the major risk factors contributing to the situation. Therefore, the search for alternative therapies for MRS infections is of paramount importance in pig production because in addition to providing protection to the animals from bacterial infections during different stages of their growth, it also reduces the environmental exposure of carriers, veterinarians, and consumers to antibiotic-resistant bacteria and resistanceconferring genes, especially through airway transmission of these microorganisms. Therefore, in future research on such isolates, we will focus on the identifying the resistance genes that may confer possible antibiotic multi-resistance to bacteria in animals used for meat production and their origins. This project was approved on 17/08/2018 by the Ethics Committee in Research Involving Animal Experiments (CEPEEA) from the State University of Londrina under protocol No. 31128/2017.

Keywords: staphylococci, slaughterhouse, genes of resistance, pcr, sus scroffa domesticus, one health

\section{RESUMO}

O objetivo deste estudo foi realizar a caracterização genética de Staphylococcus spp. resistentes a meticilina isolados de suínos. Foram coletadas 30 amostras de swab nasal de suínos, abatidos em um frigorífico com Serviço de Inspeção Federal. Os isolados foram submetidos a análises macro e microscópicas que, em seguida, para detectar a resistência bacteriana, foram submetidos a ensaios fenotípicos da sensibilidade aos antimicrobianos. Posteriormente, as amostras resistentes a oxacilina, foram submetidas à reação em cadeia pela polimerase (PCR) para verificar a presença do gene mecA. Das 30 amostras analisadas, foram isolados 12 (40\%) Staphylococcus spp. coagulase positiva, e 18 (60\%) coagulase negativa, e, dentre os isolados, 26 (86,66\%) foram resistentes a oxacilina sendo possível detectar o gene mecA em seis (23\%) amostras. Este estudo evidencia a presença de genes de resistência em microrganismos comuns a microbiota de animais de produção que podem ser transmitidos ao homem. Além de chamar a atenção para a frequência e quantidade de antimicrobianos aos quais estes animais são expostos durante toda sua vida, podendo ser considerado um problema para a saúde única.

Palavras-chave: estafilococos, frigorífico, genes de resistência, pcr, sus scroffa domesticus, saúde única

\section{ACKNOWLEDGEMENTS}

The authors thank the slaughterhouse for their collaboration and CAPES, CNPq and Araucária Foundation for financial support.

\section{REFERENCES}

AGUILAR, C.E.G.; BARALDI, T.G.; SANTOS, A.C.R. et al. Implementação e avaliação das práticas de biosseguridade na produção de suínos. Uma revisão. Rev. Bras. Hig. San. Anim., v.9, p.320-333, 2015.
BLODKAMP, S.; KADLEC, K.; GUTSMANN, T. et al. In vitro activity of human and animal cathelicidins against livestock-associated methicillin-resistant Staphylococcus aureus. Vet. Microbiol., v.15, p.107-111, 2015.

CLSI (CLINICAL AND LABORATORY STANDARDS INSTITUTE). Antimicrobial disk and dilution susceptibility tests for bacteria isolated from animals; approved Standard-4. ed. Wayne, PA, 2013. (CLSI document VET01-A4 Clinical and Laboratory Standards Institute). 
COELHO, S.M.O.; MORAES, R.A.M.; SOARES, L.C. et al. Mapeamento do perfil de resistência e detecção do gene mecA em Staphylococcus aureus e Staphylococcus intermedius oxacilina-resistentes isolados de espécies humanas e animais. Ciênc Rural, v.37, .195-200, 2007.

HUMPHREYS, H. Bacterial pathogens and associated diseases. In: GREENWOOD, D.; BARER, M.; SLACK, R. et al. Medical microbiology. Inglaterra: Elsevier. 2012. p.176178.

LIMA, E.S.C.; PINTO P.S.A.; SANTOS, J.L. et al. Isolamento de Salmonella sp. e Staphylococcus aureus no processo de abate suíno como subsídio ao sistema de Análise de Perigos e Pontos Críticos de Controle - APPCC. Pesqui. Vet. Bras., v.24, p.185-190, 2004.

MASSON, G.C.I.H.; FERREIRA. G.S.; OLIVEIRA, L.F.; CARVALHO, S. Perfil de resistência a antimicrobianos de Staphylococcus aureus isolados de granjas e frigoríficos de suínos. Arch. Vet. Sci., v.17, p.1-14, 2012.
MORÉS, N.; MORÉS, M.A.Z. Restrição do uso de antimicrobianos em suínos no Brasil: estamos preparados para esta realidade? Rev. Suinos Ind., v.39, p.34-39, 2017.

MORGAN, M. Methicillin-resistant Staphylococcus aureus and animals: zoonosis or humanosis?. J. Antimicrob. Chemother., v.62, p.1181-1187, 2008.

MURAKAMI, K.; MINAMIDE, W.; WADA, K. et al. Identification of methicillin-resistant strains of Staphylococci by polymerase chain reaction. $J$. Clin. Microbiol., v.29, p.2240-2244, 1991.

PICHON, B.; HILL, R.; LAURENT, F. et al. Development of a real-time quadruplex PCR assay for simultaneous detection of nuc, PantonValentine leucocidin (PVL), mecA and homologue mecA LGA251. J. Antimicrob. Chemother., v.67, p.2338-2341, 2012.

QUINN, P.J.; CARTER, M.E.; CARTER, G.R. Clinical veterinary microbiology. London: Wolfe, 1994. p.237-242.

RELATÓRIO anual de 2017. São Paulo, ABPA, 2018, 176p. 